\title{
Sedimentology and stratigraphy in the 1950s to mid-1980s: The story of a personal perspective
}

\author{
Northeastern Science Foundation Inc., College of the City of New York, P.O. Box 746, Troy, New York 12181-0746, USA
}

\begin{abstract}
Despite an august history of 150 years, sedimentology as a science has advanced most rapidly since about 1950. This rapid advance resulted from a change of sedimentology as a pure to an applied science. Economic incentives, particularly in the exploration for petroleum, spurred prodigious expansion and rapid advances in sedimentology. Major oil companies began to realize that sedimentology was the key to success in exploration. Recognition of the enormous value of sedimentology as a key to the discovery of stratigraphic traps represented a turning point in the history of the science. The 1947 report of the Research Committee of the American Association of the Petroleum Geologists, under the leadership of Shepard W. Lowman, Rensselaer Polytechnic Institute, stated that research in sedimentology is the most-urgent need in petroleum geology. Processresponse models and facies analysis dominated sedimentology. Convulsive and catastrophic events as sedimentological processes gained acceptance. This paper concludes with the mid-1980s after which sequence stratigraphy revolutionized the study of sedimentary deposits. This account is a personal perspective related through personal involvement in scientific societies, technical journals, and research.
\end{abstract}

\section{Introduction}

Sedimentology, a term first used by A.C. Trowbridge (1885-1971) in 1925, but formally proposed in 1933 by H.A. Wadell (1895-1962), is most simply defined as the scientific study of sediments and sedimentary rocks. The term sediment refers to regolith that has been transported. Sediment is a word derived from the Latin sedimentum, which means "a settling." Not stated, but implied, is the idea that the settling occurred through air or water. In the 1960's through mid1980's sedimentology, as defined by Friedman and Sanders (1978), was described in the widest possible sense as the geology of sedimentary deposits, and included the fields of sedimentation, diagenesis, sedimentary petrology, stratigraphy, paleogeography, and sedimentary tectonics. Sedimentology even related to concepts of the dynamics of the lithosphere, a field named megasedimentology, the scientific study of the sedimentology of vast regions, including entire sedimentary basins; lithosphere plates; or fold belts, such as the Appalachian or Alpine mountain chains (Friedman and Sanders, 1978). As these definitions show, stratigraphy at that time seemed to have been absorbed into sedimentology, yet it was more than absorption of one subject by another. Sedimentology as a subject was grow- ing dynamically and was a lot more exciting. Today we feel that these two subjects should be distinct from one another. It is a perversion to merge either with the other, rather one should consider them as equals and label them Sedimentary Geology. Yet during the 1960 's it was hard to find a geologist who identified himself as a stratigrapher. All stratigraphers had become sedimentologists.

Stratigraphy was merely a specialty of sedimentology. This definition of sedimentology was as broad as the definition of stratigraphy as expressed by A.W. Grabau (1870-1946), by C.O. Dunbar (1891-1979) and J. Rodgers (1914- ), and by J.M. Weller (18991976). The tables were turned, earlier stratigraphy used to subsume sedimentology.

\section{Sedimentology in exploration for petroleum}

Despite an august history of 150 years, sedimentology as a science has advanced most rapidly since about 1950 . This rapid advance resulted from a change of sedimentology from a pure to an applied science. Economic incentives, particularly in the exploration for petroleum (oil and gas), spurred prodigious expansion and rapid advances in sedimentology. Exploration personnel of major American oil companies began to realize that sedimentology was the key to success in exploration. Whereas previously used techniques in oil and gas exploration consisted for the most part of a search for closed subsurface anticlines, known as structural traps, emphasis shifted to exploration for subsurface stratigraphic traps in which porous and permeable sedimentary rocks are in lateral stratigraphic contact with impermeable sedimentary rocks. Such lateral contacts of different and distinct sedimentary rocks reflect differences in depositional conditions and hence two or more contiguous paleoenvironments, such as sand bars next to lagoonal muds (sandstone units next to shales in the rock record), or sandy fluvial channels juxtaposed against the muddy banks of the flood plain. Such recognition of the enormous value of sedimentology as a key to the discovery of stratigraphic traps represented a turning point in the history of the science.

The beginnings of exploration for stratigraphic traps date to the 1920s and 1930s. Thus Memoir 16 of the American Association of Petroleum Geologists titled "Stratigraphic type oil fields", edited by A.I. Levorsen in 1941 published a symposium volume on stratigraphic traps, providing a comprehensive summary of fields known at that time. But the sedimentological background for exploration for stratigraphic traps post-dates 1950 . Beginning with the recognition of sedimentology as a key to exploration, the first large-scale sedimentological research projects materialized during the mid 1950's. There had been large-scale research projects before, such as the boring of the atoll of Funafuti in the Pacific Ocean at the close of the nineteenth century, but such early efforts were isolated. Among those needing special mention is the symposium which the American Association of Petroleum Geologists published under the title of Recent Marine Sediments organized by a committee of the National Research Council edited in 1939 by Parker D. Trask. The 1947 Report of the Research Committee of the American Association of 
Petroleum Geologists, under the leadership of Shepard W. Lowman (1899-1967) of Rensselaer Polytechnic Institute (now known as Rensselaer), stated that research in sedimentology is the most-urgent need in petroleum geology. Lowman and I shared a double office suite at Rensselaer and discussed at intervals the immediate and urgent need of advances in sedimentology. As a result of the input of Lowman's committee, Project 51 of the American Petroleum Institute was organized which led to a methodical and detailed study of modern depositional environments on a scale not previously attempted. With the aid of research vessels and research teams, modern marine- and deltaic depositional environments were explored. Much of the background of this largest-of-all projects of the American Petroleum Institute was prepared by Lowman, who first conceived the idea. A classic book that emerged from this team effort was published as a special volume of the American Association of Petroleum Geologists: Recent Sediments, Northwest Gulf of Mexico. It was co-edited by F.P. Shepard (1897-1985), F.B. Phleger (1909- ), and Tj. H. van Andel (1923- ). I was involved in the production of this book in 1958-1959 as critical reviewer. Whilst working at Amoco Corporation, then known as Pan American Petroleum Corporation, my boss A.F. Frederickson (1918- ), served on the American Petroleum Institute Research Project Committee representing our company. He was a member of the Book-Review Committee, and he assigned the job of reviewing the manuscripts to me to be handled on week-ends and evenings. However, my name is not included in this volume. As custom had it, I was acknowledged twice a month when the pay check arrived.

In the research laboratories of the major oil companies, such eminent team leaders as H.N. Fisk (1908-1964) of Exxon (formerly Humble), a student of deltas; H.A. Bernard (1915-1975), and R.J. LeBlanc, Sr. (1917- ) of Shell, pioneers in the study of fluvial sedimentology; and R.N. Ginsburg (1925- ), of Shell, researcher in carbonate sediments, gave modern sedimentology a boost that led to rapid breakthroughs and advances. Sedimentology owes a great debt of gratitude to the major oil companies for pioneering in large-scale research projects and for making this information available to the profession at large through the regular channels of publication. I held a comparable research position to that of the team leaders just mentioned, working with Amoco Corporation, and initiated work on modern carbonate and clastic depositional environments, as well as on petroleum-bearing sequences across North America. These were heady times. In November 1957 Pan American discovered the Empire Abo field, a Permian barrier-reef reservoir in New Mexico. This field is a giant stratigraphic oil accumulation that was discovered employing classic stratigraphic principles. Following this discovery, management felt that geoscientists of other company district and division offices needed immediate training in carbonate geology. As a result, one of my tasks became that of setting up a carbonate training program. We studied the Permian carbonates of the Guadalupe Mountains of west Texas and New Mexico.

In several carbonate seminars our frustration in studying bedrock exposures of the Guadalupe Mountains were the result of our inability to relate these products of sedimentation to the processes that formed them. We discovered the importance of process sedimentology, but knew nothing about the processes themselves. After one of these field trips I approached our vice president for exploration with our need for understanding sedimentological processes. He agreed with me that process sedimentology is critical and further concurred that a study of processes in modern depositional environments is justified. On leaving his office, he asked where I would go to study processes. I responded that the Bahamas Platforms would be the most ideal study area, whereupon he looked at me strangely and replied "you want to go to the Bahamas, I have not been to the Bahamas, and if anyone goes it will be me. You go back to West Texas". Several months later I conducted another field program. As habit had it, most trips were run in August, when the temperatures in the field soared to $45^{-} \mathrm{C}$, as measured in the shade, and there was no shade. One of the participants was a division superintendent and close friend of the vice president for exploration with whom he played golf on the Sunday after our return. During their game they discussed our field trip, and on Monday morning the telephone rang in my office at 7:45 a.m. The vice president ordered me to his office right away. On my arrival there we chatted several minutes about the heat wave in the field, but then the vice president turned to me with the words "Gerry, I am disappointed in you". If a vice president is disappointed in you--this is no easy matter. I asked what was the source of his disappointment, and he blurted out "a good explorationist must be process-orientated, and you are not process-orientated enough." I was stunned, because I had been selling this same message for months, if not years, but he was right in that I had no experience with processes and admitted it. When I asked him what his suggestion may be, he almost shouted: "Why don't you go to the Bahamas". Although several months earlier he had turned down my request for a Bahamas program, this time the idea was his, and I answered "I should have thought of that myself". At Pan American I made sure that good ideas seemed to emanate from the vice president, and never from me. I do not know if other companies had parallel experience, but I insisted to my staff that the vice president wanted us to be more process-orientated, which necessitated our field program in the Bahamas and elsewhere.

Following successful carbonate seminars, management agreed to offer sandstone seminars. The first phase related to principles of clastic deposition as seen in the modern deposits of the coastal area of the Gulf of Mexico. We convened in San Antonio, and from the air studied the shoreline of the Gulf of Mexico between the Mexican border and Houston, then examined on the ground barrier islands of the Texas coast, and by boat and plane compared the various environments of the Mississippi delta. The principal locale for the second phase was in the Book Cliffs area of Utah and Colorado. Here, the Upper Cretaceous Mesa Verde Group provided excellent examples of ancient counterparts. During the third phase of the seminar, held at the Research Center in Tulsa, Oklahoma, lectures and exercises emphasized the length and breadth of the subject from process sedimentology to mechanical logs, seismic techniques, and reservoir case histories. Interestingly, still today, 35 to 40 years later, companies take geologists to the same places for their carbonate and sandstone seminars. Check the offerings of field seminars in a recent AAPG Explorer, and you will note the same places listed for study.

Although in theory there was almost no cross fertilization of ideas between companies, informally much cooperative work existed within committees of the American Association of Petroleum Geologists (AAPG) and Society for Economic Paleontologists and Mineralogists (SEPM). In addition personal contacts counted. As examples, let me cite once again the names of the eminent leaders of the research laboratories of the major oil companies Fisk, Bernard, LeBlanc, and Ginsburg. Harold (Hal) N. Fisk, student of deltaic sedimentology, received his Ph.D. degree at the University of Cincinnati under John L. Rich (1884-1956), my chairman at that university, and Otto Von Schlichten (1886-1950), my predecessor. On his frequent visits while I was on the faculty, at the University of Cincinnati and after joining Pan American Petroleum Corporation, we consulted frequently problems of mutual interest: what to do to advance the science of sedimentology. H. (Hugh, Barney, Boo) A. Bernard, student of fluvial sedimentology almost lost his life on the Brazos River in Texas under flood conditions, when his boat spun around out of control during a hurricane. He recounted this experience to me in our discussions of the relationships of point-bar sequences to floods. By the late 1950s, he had attained international recognition as one of the world's foremost authorities on fluvial, deltaic, and barrier-island sedimentation. Unfortunately Bernard died of diabetes before the relevant geological societies recognized his contributions, although he did gain some of the recognition he deserved by virtue of being the principal organizer of a symposium on Deltaic Sedimentation which the (SEPM) Society of Economic Paleontologists and Mineralogists held in New Orleans, Louisiana, in 1965. R.J. LeBlanc, Sr. (1917- ), who was Bernard's close colleague, provided me with illustrations and information for my coauthored textbook with J.E. Sanders on sedimentology. R.N Ginsburg (1925- ) was my fellow student at the University of Wyoming 
late 1940 's, and we spent time together discussing carbonate sedimentology in the 1950's, 1960's, and 1970's.

\section{The golden age for sedimentary geology}

Following the retirement of Lowman in 1962, I took over as professor of sedimentary geology at Rensselaer. My appointment in 1963, to start service in 1964, coincided with the beginning of the "Golden Age of Sedimentary Geology". As already pointed out, at that time stratigraphy had become part of sedimentology. Hence, in keeping with the rest of the geological world, the Rensselaer program in sedimentary geology became known as the Rensselaer Sedimentology Program. I transferred to Rensselaer to take on two responsibilities: firstly as an educator in sedimentology and secondly as Editor of the Journal of Sedimentary Petrology, which published the results of research in sedimentary geology for the Society of Economic Paleontologists and Mineralogists, now known as SEPM - Society for Sedimentary Geology. My task was to guide this journal into the upcoming boom of the 1960's and 1970's. In the late 1950's Editor Jack L. Hough (1909-1985), in his "editor's note on the state of the journal" (1957, p. 476) wrote "investigators in the field of sedimentary petrology are urged to consider the Journal of Sedimentary Petrology (JSP) as a primary outlet for their manuscripts". Although already 26 years old at that time, JSP was yet pedestrian and good papers went elsewhere (e.g. Geological Society of America Bulletin, Journal of Geology, American Journal of Science, non-U.S. journals). My task was to turn the journal around. By 1969, JSP not only had become the leading international journal in sedimentary geology, but its total published pages exceeded that of any volume published before. In fact, 21 years later the 1990 volume published approximately $30 \%$ less than that of 1969 . I used up the entire annual budget which SEPM provided for the Journal of Sedimentary Petrology (JSP) in publishing its first two annual issues. The funds for the third and fourth issues I raised through page contributions and requests from petroleum corporations. On one occasion F.P.Shepard graciously donated a major sum of money to pay for the fourth issue. Thus creative financing, with the help of sponsors, pushed JSP to the forefront in its publication record and its task of advancing the field of sedimentology.

As already noted, the 1960's is referred to as the Golden Age for sedimentary geology, and as Editor of the Journal of Sedimentary Petrology I was in the midst of the action. What made the developments of the 1960's and 1970's so exciting was the realization that various kinds of formative processes may yield essentially the same products. Thus the product itself might not convey information pointing to a single specific process, but may be the result of interaction between by two, three, or more processes. In dealing with the geologic record, sedimentologists are confronted with products of associated processes, which operated collectively in what we know as depositional environments, not with the products of processes that operated in isolation. We can define a depositional environment as a natural geographic entity in which sediments accumulate. In attempting to infer the history of a sedimentary deposit, a geologist needs to do more than simply infer the physical- or chemical processes that operated. The ultimate goal is reconstruction of the pattern of ancient depositional environments. This is not easy, because what appears to be a single sedimentary product may have formed by contrasting processes operating in different depositional environments. For example, large-scale planar cross strata are known from modern eolian sand dunes, from linear submarine sand ridges, and from sand bars deposited by large rivers.

An experience of a sedimentologist who had studied the characteristics of supposed ancient river deposits in a Midcontinent area of the United States is a case in point. The sedimentologist had used all the latest approaches in the physical analysis of the strata: he had analyzed the bed forms, measured directions of dip of cross strata, and finally had worked out a three-dimensional interpretation. On a field trip, a paleontologist discovered fossils that proved the strata were marine. The revised interpretation in light of the marine fossils was that the supposedly fluvial deposits had been deposited under intertidal conditions in a marginal-marine environment. Some of the physical characteristics of sediments deposited in intertidal channels are similar to those deposited in fluvial channels. Although some minor differences exist that can enable one to distinguish the products of these two environments without the fossils, such differences are not always readily apparent. Thus one ecologically diagnostic fossil is worth a myriad of inorganic features for environmental determination. It is troubling that young sedimentary geologists know so little paleontology in today's highly specialized world.

The aspect of a sedimentary deposit that reflects the depositional environment is known as the facies, which is defined here as the lithologic- and paleontologic characteristics of a sedimentary deposit, imparted by the depositional environment. The term facies, initially used by Nicolaus Steno (1638-1687) in 1669 to express a fundamentally important concept in geology, proved to be so useful that multiple definitions proliferated. Steno and Leonardo Da Vinci (1452-1519) before him, had rudimentary ideas about differing sediment types and organisms in different environments, but Amanz Gresley (1814-1865) deserves credit for the formal introduction of this term into geology in 1838 for exposures of Jurassic strata in the Jura Mountains of Switzerland (Cross and Homewood 1997).

In these years the science of sedimentology progressed from a study of heavy minerals, provenance, and thin sections, the hallmark of the 1930's to 1950 's, to facies analysis, and process sedimentology. A peek at a single issue of the Journal of Sedimentary Petrology of the middle to late 1960's shows its overwhelming breadth, depth, and variety. The concepts covered included physical-, biological-, and chemical processes, circulation in the atmosphere, in modern oceans, and in basin waters, and the Earth's important environments of deposition, such as deep-water basins, basin margins, and nonmarine environments. Process- response models were developed, which related sedimentary processes to their products, and in the 1960's and 1970 's these models became the key to sedimentology.

Sedimentologists start with features in the geologic record and work backward to infer depositional processes and depositional environments. In doing so, they employ scientific reasoning that is specific to geology and foreign to many but not all other fields of science. In physics and chemistry, for example, known processes are followed in carefully controlled experiments to see what unknown products will result. After the products have formed, they are directly observable and can be related exactly to the formative processes. The reasoning is forward from process to product. By contrast, in many geological investigations the rock is the known product and the formative processes are the unknowns. Instead of doing the experiment and seeing the result, a sedimentologist starts with the result and asks, in effect: "What was the experiment?" Thus the sedimentologist unravels the results of those natural "experiments" that may have taken place millions, or even hundreds of millions, of years ago. In addition, of course, sedimentologists also use experimentation in the standard scientific sense to elucidate processes, for example through the use of flumes and wave tanks. Ours is not the only "historical science" that practises what has come to be termed postdiction. Astronomy, anthropology, and evolutionary biology use this approach as well.

This paper is titled "a personal perspective", hence this next paragraph may sound like a resume, but its purpose is to show my involvement and responsibility with sedimentological organizations which helped me recruit research results as publishable papers that advanced the science of sedimentology. In 1970 I ended my tenure as Editor of the Journal of Sedimentary Petrology and became Vice President (1970-71) and then President (1974-75) of the SEPM. Yet another society serves sedimentary geology besides SEPM, namely the International Association of Sedimentologists (IAS), which publishes the journal Sedimentology. IAS was formed in 1946, in Europe, and its journal begun in 1962. During 1971 to 1975 I served as Vice President of IAS and while the association's only Vice President, I also served as SEPM President. From 1975-1978 I was IAS President, and became the only scientist ever to hold the presidency 
of both the national (SEPM) and international society (IAS) in sedimentary geology. I served a total of twenty years on the Council of SEPM and the Bureau of IAS, and as already noted, during this time actively recruited research papers in sedimentology for publication, especially for JSP and various research symposia. I was still in the midst of the action in sedimentary geology throughout the 1970's and into the early 1980's. My term of office in IAS terminated in 1982, and I served as National vice president of AAPG from 19841985. Hence my discussion of sedimentology and stratigraphy in the 1960 's to mid-1980's stops in 1985, when I completed my last responsibility as an officer of sedimentological organizations. As will be mentioned later the new concepts of sequence stratigraphy, which do not form part of this paper, involve the post-1985 era.

\section{Sedimentology, plate tectonics, and the geosyncline}

During the late 1960's and 1970's the concept of plate tectonics became progressively accepted as a viable doctrine. Facies as well as stratigraphy and tectonics could now be related to the plate-tectonic paradigm. At that time John (Jack) M. Bird (1931- ) completed his Ph.D. degree under Lowman at Rensselear on a quadrangle in Rensselaer County, New York, in the heart of the Northern Appalachian Mountains. In his thesis he expressed his thanks to Lowman for his "knowledge and insight of sedimentology (which) have greatly benefited the writer and his research." Bird moved across the Hudson River from Rensselear to a position at the State University of New York (SUNY) in Albany, and was joined by John F. Dewey (1937- ) from England. Using the northern Appalachians as a case history, Bird and Dewey collaborated on their classic papers on plate tectonics titled Lithosphere Plate -- Continental Margin Tectonics and the Evolution of the Appalachian Orogen (1970) and Plate Tectonics and Geosynclines (Dewey and Bird, 1970a,b). These studies emphasized the importance of horizontal plate motions for the generation of vertical movements of the Earth's crust. Their insistence on lateral motion was so strong that Dewey and his colleague Kevin C.A. Burke (1929- ) requested me to remove all discussion of vertical motion from my co-authored textbook Principles of Sedimentology (Friedman and Sanders, 1978). The consensus was "there is no such thing as vertical tectonics; all tectonic movements are laterally driven". In compliance with the reviewers' requests, but under duress, the subject of vertical motion was removed from our textbook. Today vertical tectonics is a hot subject in basin analysis. Hence it was not until the second revised edition of my co-authored textbook (Friedman, Sanders, and Kopaska-Merkel, 1992) that vertical motion in sedimentary tectonics was reinserted. Despite Bird and Dewey's advance, through the 1970s, facies and sedimentary basins were still analyzed in terms of the concept of the geosyncline. However, a revolution had already begun in the 1960's and by the end of the 1970's all of sedimentology and stratigraphy had changed. Basin analysis focused, as it does today, on the analysis of sedimentary basins with respect to their origin as inferred from the concepts of plate tectonics.

In discussing sedimentology of the 1960's and 1970's, the concept of the geosyncline should be briefly reviewed. This concept was inspired by the geologic relationships that were worked out for the northern Appalachian Mountains. The originators of the geosynclinal concept were James Hall (1811-1898) and James Dwight Dana (1813-1895). James Hall was an alumnus of Rensselaer and beside being state geologist of New York served on the Rensselaer faculty. Dana owed his interest in geology to his teacher Fay Edgerton (1803-1832), likewise an alumnus of Rensselaer. Hall observed that where the Paleozoic marine strata in the interior of North America are thin (thicknesses of only a few hundreds or a few thousands of meters), they are flat lying. By contrast, in the Appalachians, thicknesses of equivalent strata amount to tens of thousands of meters and the strata are no longer horizontal. Hall (1859) hypothesized that the subsidence of the strata within a trough, where they would be extra thick, provided the mechanism for folding them. Shortly afterward, in 1873, James Dwight Dana argued that subsidence alone could not fold the strata. Instead, Dana proposed that the strata had become thick by sinking unmolested in a great synclinal trough (which he named a geosynclinal, later renamed geosyncline). According to Dana, only afterward were these thick, trough-filling strata folded. Dana suggested that the deformation of the crust beneath a geosyncline was the cause of subsidence and sedimentation and also the cause of the subsequent deformation of the sedimentary strata and concomitant mountain building.

Both Hall and Dana emphasized an important inference about the Appalachian area, which was that it had subsided. This inference stated that throughout the thousands of meters of vertical sinking, the depth of the marine waters had remained "shallow." In other words, subsidence had been more or less exactly matched by accumulation of sediment. The original idea that a part of the sea floor might subside and yet sediment could accumulate fast enough to keep the water depth from changing very much had been published by Charles Darwin (1809-1882). In the Appalachians this relationship between great subsidence and the existence of thick shallow-water sediments was so striking that it was made part of the "geosynclinal doctrine." According to most American geologists, the identifying characteristic of a geosyncline was that it is a place where subsidence proceeds at a rate exactly matched by the rate of sedimentation. To these American geologists, "geosyncline" became synonymous with continuously shallow water.

Through the 1970s, basins were analyzed in terms of the concept of the geosyncline. Classical stratigraphy, as practiced by most stratigraphers, placed little emphasis on the analysis of genetically related groups of strata that form what we call sequences. A revolution had already begun in the 1960s, and by the end of the 1970s all of sedimentology and stratigraphy had changed. Basin analysis focused, as it does today, on the analysis of basins with respect to their origin as inferred from the concepts of plate tectonics. The study of the sedimentary fill of basins, stratigraphy, had begun the shift that continues today.

In line with this discussion I want to relate two anecdotes, both of the 1950's. In 1953 Lawrence H. Lattman (1923- ) took his Ph.D. examination at the University of Cincinnati. I was one of his examiners. The others were a distinguished group of sedimentary geologists and paleontologists: John L. Rich (1884-1956), Gordon Rittenhouse (1910-1974), and Kenneth E. Caster (1908-1992). Two hours were spent discussing sedimentation patterns in geosynclines. I tried to steer questioning into other areas of stratigraphy. To my shock all three colleagues protested and contended almost at a high-pitched decibel level, that only geosynclines really mattered. Almost to the closing bell, the examination proceeded with elaboration on the geosyncline. This account explains the importance of the concept of the geosyncline to the geological community of the time. Now, it is surprising in terms of historical analysis of ideas that the term geosyncline is not even listed in the subject index of current textbooks of stratigraphy and basin analysis.

The second anecdote, relates to a Ph.D. examination at Columbia University at about the same time. This story is hearsay; I was not present but remember Walter H. Bucher (1888-1965) talking about it. The candidate explained the origin of the modern Atlantic Ocean as a result of continental drift, a concept that was the forerunner of plate tectonics. The members of the examination committee did not think that continental drift was a viable process for the creation of the Atlantic Ocean. They challenged the candidate to provide the geophysical basis for the process of drifting of the continents which, of course, before plate tectonics he could not do. So the candidate failed and never received his Ph.D. degree. No wonder Robert Dietz (1914-1995) claimed that Walter Bucher put geology "50 years behind." Dietz surely exaggerated, but he made his point that the concept of the geosyncline was so entrenched that it challenged the early acceptance of continental drift and plate tectonics. 


\section{Process sedimentology and environments of deposition}

With the breakthroughs in process-response models and facies analysis and as a response to the rapid expansion and diversification of sedimentology, my colleague John E. Sanders (1926- ) and I believed that a critical synthesis of this field is a matter of importance and urgency. So in the summer of 1971 we started writing a textbook titled "Principles of Sedimentology" which was completed in the spring of 1976 and published in the summer/ fall of 1978. We prepared this book as a comprehensive summary of the geology of sedimentary deposits. We intended to include the bases for interpreting sedimentary deposits in terms of processes, environments of deposition, vertical successions of strata, and sedimentary tectonics. The way we approached the vast domain of sedimentology differed from that followed in several well-known books entitled Sedimentary Rocks or Sedimentary Petrology. In most of these books, which were widely used for teaching undergraduate courses dealing with sedimentary deposits, many chapter headings were the names of sedimentary rocks, such as sandstones, shales, limestones, evaporites, coal, zeolites, and so forth. Although we discussed sedimentary rocks and acknowledged the value of a major organization built around individual rock types, we preferred a chapter organization that emphasized the dynamic aspects of sedimentology. The central core of the book was sedimentary environments and facies. One of the several ways of analyzing the complex array of subjects that must be understood in order to make detailed comparisons between the products of modern depositional environments and those of ancient depositional environments now found in the geologic record is to organize the material on environments under the headings of "depositional models" or "depositional systems." We tried to do this without highlighting either the term "model" or "system."

Our textbook was an immediate success; within a few months the first printing was sold out. I remember going on a trip to southeast Asia to teach a short course and needed fifty books. None were available, but finally I located one hundred copies, which were stored in Salt Lake City. I bought the lot. Choice Magazine singled out this book as part of its list of Outstanding Academic Books of 1979. Within the next few years, nine domestic and three international printings followed in rapid order, and the book was republished in China, Taiwan, Korea, and Indonesia. When I gave a short course in China, all students owned a copy of the book published in Chinese.

In 1974 when I served as vice president of the International Association of Sedimentologists Harold G. Reading (1924- ) was secretary and Mme. Y Gubler was president. I discussed with both the progress of our textbook and requested Reading to review some chapters. Reading had parallel ideas, and was planning a book that would bring together specialists who would write chapters on facies and sedimentary environments which he would edit. During this discussion in Mme Gubler's living room in Paris, France, we decided, however, that it would not be appropriate for him to review chapters of our book nor for me to write chapters for his book. Reading's (1978) book was an instant success and helped promote the new developments in the field of facies analysis and depositional environments.

\section{Sedimentology and catastrophic events}

Another field of endeavor affected sedimentology and stratigraphy and upset the Lyellian basis of uniformitarianism. The uniformitarian concept emphasized the slow steady-state, evolutionary processes of the kind that humans observe and experience on a daily basis. At the beginning of the 1980's this emphasis shifted to catastrophic or convulsive events. I like to reminisce on this point from the vantage of personal experience. In 1978/79 I became chairman of the Geology and Geography Section (Section E) of the American Association for the Advancement of Science (AAAS) and then became Council Delegate of AAAS. My assigned duty was to plan and organize symposia for the next annual convention. Together with the other section delegates, section chairs and council delegates we put together excellent symposia for the 1980 annual meeting to be held in San Francisco. However, curiously, at this meeting a program had sprung up that had not been planned and came as a complete surprise. This non-planned program centered around a Nobel laureate physics professor, and was not even listed in the AAAS 1980 program. The featured speaker was Luis Alvarez, professor of physics emeritus and associate director at large of the Lawrence Berkeley Laboratory, California. In the 1980 program, where I was listed as retiring chairperson of Section E-Geology and Geography, he was shown as a member of the "San Francisco Advisory Committee" and his function on the program as "Youth Symposium, Frontiers of Science, and Session Aides Subcommittee." Yet the title of his paper was not in the formal program. Together with three coauthors, including his geologist son Walter, and two analytical chemists, who where specialists in the analyses of platinum and iridium, he presented to an unbelieving audience that an asteroid of $10^{4}$ kilometers diameter struck the Earth at the end of the Cretaceous and caused mass extinction. This bold proposition resulted from their discovery, near the medieval town of Gubbio, Italy, of a centimeterthick clay layer among limestones that straddled the Cretaceous-Tertiary boundary. They found that the clay contained $6.3 \mathrm{ppb}$ of iridium which compared with a crustal iridium abundance of less than $0.1 \mathrm{ppb}$. They surmised that extraterrestrial sources, namely an asteroid, produced the iridium anomaly. This unplanned presentation, together with its speculation, unnerved me. How much do we know about the distribution of iridium in the various lithologies of the Earth's crust? The speaker did not reveal abundances, but dwelled on the difficulty of iridium analyses in which his chemist-coauthors were involved. I asked him that if extinction at the Cretaceous-Tertiary boundary was the result of an asteroid impact, then what had happened at the Permian/Triassic boundary, when extinction of life was more calamitous than at the Cretaceous/Tertiary boundary. Alvarez answered that as a physicist his thoughts were: if an impact had afflicted the Earth's biosphere at the Cretaceous/Tertiary boundary, a similar event must have extinguished life at the end of the Permian. I made the point to the speaker that I thought his paper was poor science. Wow! In hindsight, what a nerve! Several months later at the Albany, New York, airport I met Kevin C.A. Burke who had returned from a conference in the western United States which Alvarez had convened. Burke was convinced by the impact theory. Alvarez et al.'s (1980) paper meanwhile had been published and has had a crucial effect on our views of sedimentology. Still, my initial reaction to Alvarez's presentation has been sustained. According to Orth et al. (1988) and Kitz (1996) the relation between iridium anomalies and mass extinction is circumstantial, very suggestive, but not compelling. At the Permian - Triassic boundary, about which I asked Alvarez, no significant iridium anomaly has yet been found (Orth et al., 1988; Kitz 1996). The popular image of the CretaceousTertiary boundary is one of rapid extinctions related to catastrophic events. Yet no consensus exists at present as to causes. Environmental stress, volcanic activity, and meteoric impact are among the causes cited. Large-scale extinctions do not necessarily have an extraterrestrial mechanism (Sims, 1997).

In 1982, my successor as President of the International Association of Sedimentologists, Kenneth J. Hsü (1929- ), emphasized in his address as the association's retiring president, the importance of catastrophic events. His address and his 1983 published version were titled Actualistic Catastrophism. At our final bureau meeting in 1982 at McMaster University in Canada, I related to him my experience with the Alvarez presentation, which I have just discussed. The asteroid-impact hypothesis for the extinction at the Cretaceous/Tertiary boundary has led to new ideas about the importance of convulsive and catastrophic events as sedimentological processes, even if no connection may exist between convulsive events and mass extinction. 


\section{Post - 1985 sequence stratigraphy}

This paper concludes with the mid-1980's. Although Vail et al.'s classical study on seismic stratigraphy was published in 1977, the general geological community did not embrace it until the 1980's, especially after 1985 when Van Wagoner's classical abstract was released by Exxon for the mid-year SEPM meeting in Denver. Since the mid-1980's sequence stratigraphy revolutionized the study of sedimentary deposits. This approach predicts the distribution of facies based on the response of depositional environments to changes in base level. During the past two decades, study of continuous seismic reflection profiles, particularly of the prisms of sediment underlying the modern continental terraces and continental rises, by members of the Exxon Production Research Laboratory in Houston, Texas, has brought into the forefront of geological thinking the importance of the base-level control of sediment deposition. Many geologists have long appreciated the importance of base-level control on the patterns of sediment deposition, but when the scope of the relationships has been enlarged to basinwide scales, new understandings have appeared. These new concepts of sequence stratigraphy, do not form part of this paper; they require a separate discussion involving the era of the 1980's and 1990's, especially the time after 1985.

\section{Conclusions}

In summary, sedimentology and stratigraphy have undergone enormous changes in the 1960's to mid-1980's. In the 1960's, all stratigraphers had become sedimentologists. Facies analysis and sedimentary processes became the hallmark of the science of sedimentary geology. Following break throughs in process-response models and understanding of depositional environments, plate tectonics provided a larger genetic context. The concept of the geosyncline was de-emphasized and basin analysis focused on the analysis of basins with respect to their origin as inferred from the concepts of plate tectonics. Finally, the asteroid-impact hypothesis drew attention to the importance of convulsive events in the rock record. This paper concludes with the mid-1980's before sequence stratigraphy which once again revolutionized the study of sedimentary deposits.

\section{Acknowledgments}

Thanks are extended to J. Bass, R. Dott, and J. Sanders for helpful reviews of drafts of this paper.

\section{References}

Alvarez, L.W., Alvarez, Walter, Asaro, Frank, and Michel, H.V., 1980, Extraterrestrial cause for the Cretaceous-Tertiary extinction: Science, v. 208, pp. 1095-1108.

Bird, J.M., and Dewey, J.F., 1970, Lithosphere plate-Continental margin tectonics and the evolution of the Appalachian orogen: Geological Society of America Bulletin, v. 81, pp. 1031-1060.

Cross, T.A., and Homewood, P.W., 1997, Amanz Gresley's role in founding modern stratigraphy: Geological Society of America Bulletin, v. 109, pp. 1617-1630.
Dana, J.D., 1873, On some results of the earth's contraction from cooling, including a discussion of the origin of mountains and the nature of the earth's interior: American Journal of Science, 3rd ser., v. 5, pp. 423-443; v. 6, pp. 6-14, 104-115, 161-172.

Dewey, J.F., and Bird, J.M., 1970a, Mountain belts and the new global tectonics: Journal of Geophysical Research, v. 75, pp. 2625-2647.

Dewey, J.F., and Bird, J.M., 1970b, Plate tectonics and geosynclines: Tectonophysics, v. 10 pp. 625-638.

Friedman, G.M., and Sanders, J.E., 1978, Principles of Sedimentology. Wiley \& Sons, 792 p.

Friedman, G. M., Sanders, J. E., and Kopaska-Merkel, D. C., 1992, Principles of Sedimentary Deposits: Stratigraphy and Sedimentology. Macmillian Publishing Company, $717 \mathrm{p}$

Hall, J., 1859, Paleontology: volume III, containing descriptions and figures of the organic remains of the Lower Helderberg Group and the Oriskany Sandstone: New York Geological Survey, Natural History of New York, pt. $6,532 \mathrm{pp}$.

Hsü, K. J., 1983, Actualistic catastrophism: address of the retiring President of the International Association of Sedimentologists: Sedimentology, v. 30, pp. 3-9.

Kitz, Norman, 1996, Mass extinctions and asteroids: a synthesis: Geoscientist, v. 6, No. 2, pp. 14-17.

Levorsen, A.I ., ed., 1941, Stratigraphic type oil fields: American Association of Petroleum Geologists, $902 \mathrm{pp}$.

Orth, et al., 1988, Iridium abundance pattern across bio-event horizon. In Sharpton, V. L. \& Ward, P. E., eds., Global Catastrophies in Earth History: An Interdisciplinary Conference on Impacts, Volcanism, and Mortality. Geological Society of America, Special Paper No. 147, pp. 45-59.

Reading, H. G., ed., 1978, Sedimentary environments and facies. Blackwell Scientific Publications, Oxford, $557 \mathrm{pp}$.

Shepard, F. P., Phleger, F. B., and van Andel, Tj. H., eds., 1960, Recent sediments, northwest Gulf of Mexico, American Association Petroleum Geologists, $394 \mathrm{pp}$

Sims, Catherine, 1997, Determining the extinction pattern at the CretaceousTertiary boundary: Geoscientist, v. 7, pp. 13-17.

Trask, P. D., ed., 1939, Recent sediments -- a symposium: American Association of Petroleum Geologists and London, Thomas Murby \& Co., 736 pp.

Vail, P.R., Mitchum. R.M., Jr., Todd, R.G., Widmier, J.M., Thompson, S.,III, Sangree, J.B., Bubb, J.N. and Hatlelid, W.G., 1977, Seismic stratigraphy and global changes of sea-level. In: C.E. Payton (Editor), Seismic Stratigraphy-Applications to Hydrocarbon Exploration. American Association of Petroleum Geologists Memoir, v. 26, pp. 49-212

Van Wagoner, J.C., 1985, Reservoir facies distribution as controlled by sealevel change, (abs.): Society of Economic Paleontologists \& Mineralogists Mid-Year Meeting, Golden, Colorado, August 11-14, pp. 91-92.

Gerald M. Friedman is currently the president of the Northeastern Science Foundation affiliated with Brooklyn College, Rensselaer Center of Applied Geology. He also serves as Distinguished Professor of Geology in the Department of Geology, Brooklyn College and Graduate School of the City University of New York.

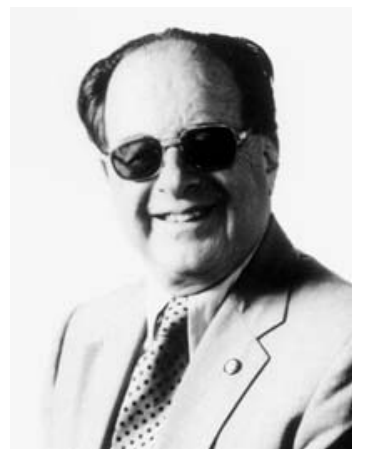

